\title{
Apoptosis in Denervated Skeletal Muscle
}

\author{
Apoptosis en Músculo Estriado Desnervado \\ "Giovanna Castilho Davatz; **Jesus Carlos Andreo; **Antonio de Castro Rodrigues; \\ ***:Geraldo Marco Rosa Júnior \& *** Luiz Henrique Rapucci Moraes
}

DAVATZ, C. G.; ANDREO, J. C.; RODRIGUES, C. A.; ROSA JÚNIOR, G. M. \& MORAES, R. L. H. Apoptosis in denervated skeletal muscle. Int. J. Morphol., 25(3):529-536, 2007.

SUMMARY: The apoptosis phenomenon happens in normal tissues and in many pathological conditions as described by several researchers. Most studied in the 70s, this phenomenon remained almost forgotten in the 90s, when, with the advent of more advanced techniques, returned to laboratories. Thus, electronic microscopy, Comet Assays and histochemistry techniques, among others, were utilized in an effort to elucidate in a thorough way, the mechanisms that lead the cell to "suicide". No one can deny the importance of the knowledge of such phenomenon, so as to control its induction or blocking in the treatment of pathologies such as cancer. In this work, the apoptosis study was aimed at denervated muscles in different periods. Furthermore, two types of skeletal striated muscles were compared: the one called red muscle (soleo) which is resistant to fatigue, having a slow contraction, and the one named white muscle (EDL) of precocious fatigue and fast contraction. Previoulsy carried out in the techniques mentioned above, this work has been accomplished using the TUNEL technique, which is most accepted in the identification of apoptosis. It was demonstrated that this phenomenon takes place in a more marked way, in the beginning of the denervation process. In addition, it was observed that the red muscle responds more intensely to denervation than the white muscle. One can infer that the removal of the main cell function, the contraction, in the case of the skeletal striated muscle, triggers the chain reactions that culminate in apoptosis. Other projects are in process using mutant animals aiming at studying degenerative muscular illnesses and correlating them with denervation.

KEY WORDS: Skeletal muscle; Denervation; Apoptosis; Rat.

\section{INTRODUCTION}

Countless alterations happen in the peripheral nerve and in the muscle innervated by it in the event of a nervous damage (Washabaugh et al., 2001). In this muscle, as the denervation time elapses owing to the decrease of contractive structures and alterations in the number of membranous organelles, there is a reduction in myosin and actine syntheses, which in turn results in a decrease in the size of fibers and resorption of myofibrils (Tischeler et al., 1990; Weis et al., 2000; Borisov et al., 2001; Washabaugh et al.

Recent studies show that in the denervated muscle, a strong immune-reactive action related to proteins such as Bcl2 and Bcl-XL takes place, as well as the increase in the rate of DNA fragmentation, activated by a mechanism of programmed cellular death, also known as apoptosis (Tang et al., 2000).

The term apoptosis has been used since 1972, in researches accomplished by Kerr and collaborators, when the basic characteristics were described through its morphologic aspects that involve condensation of the chromatin, fragmentation of the nucleus, loss of the adherence between the cells and DNA fragmentation (Zimmermann et al., 2001).

The morphological changes observed in the apoptotic cell result from an orchestrated mechanism that happens inside the cell, where proteases that are part of a great family of proteins known as caspases, participate (Hengarthner, 2000; Zimmermann et al.).

In most tissues, the activation mechanism of the caspases happens through either extrinsic or intrinsic ways. In the extrinsic way, the apoptotic signal begins by the union of extra cellular ligands to the surface of cell receptors, resulting in a recruitment of the cytosolic adapter of proteins, that activates the caspase- 8 or caspase-10 initiator, and subsequently, the caspases effectors $-3,-7$ and possibly -6 .

* Department of Fonoaudiology, FOB / USP, Bauru, São Paulo, Brazil.

** Department of Biological Sciences, FOB / USP, Bauru, São Paulo, Brazil.

${ }^{* * * *}$ Post-graduation students, FOB/USP/Bauru, São Paulo, Brazil.

FAPESP Process \# 2005/02609-6. 
The intrinsic way involves the activation of the mitochondrial c cytochrome in the cytosolic for the regulation of the family of proteins Bcl-2, stimulating the activation of the caspases for the formation of a great compound with proteins called Apaf-1 and procaspase-9. The caspase -9, subsequently, activates the caspase effectors $-3,-7$ and possibly -6 (Grütter, 2000; Hengarthner).

By the participation of proteins such as Bcl-2 and Bcl$\mathrm{XL}$, with an increase in the caspase- 9 expression which begins the proteolitic cascade, thus activating the caspase- 7 effector, leading to the loss of denervated muscular fibers (Tews et al., 2005), the denervation process might provoke an intrinsic 'suicide' program (Tang et al.).

However, authors highlight that this type of cellular death differs from that found in other tissues, since a very similar way should be activated to eliminate cells in the muscular development (Borisov \& Carlson, 2000).

Continuing the study of this phenomenon, already developed by our group (Rodrigues \& Schmalbruch, 1995; Rodrigues et al., 2005), through other techniques, we decided by means of the TUNEL technique which is the most accepted technique for marking this phenomenon (Gavrieli et al., 1992; Knaapen et al., 2001; Van Cruchten \& Van Den Broeck, 2002), to confirm the occurrence of apoptosis in two muscles (red and white), submitted to experimental denervations.

\section{MATERIAL AND METHOD}

Animals used. Thirty male Wistar rats born between August 3 and 4, 2005, coming from the Central vivarium of FOB / USP / Bauru, were utilized. It is worth mentioning that females were not used, so as to avoid possible variations in the results, deriving from the different phases of the estral cycle.

From birth to the time of surgeries and, following these, up to the date of sacrifice, the animals were kept in the vivarium, in groups of 5 per cage, having access to water and food ad libitum.

Surgeries. The animals were anesthetized with $30 \mathrm{mg} / \mathrm{kg}$ pentobarbital (Hypnol), i.p, with the needle positioned in an approximate angle of $45^{\circ}$ in the abdomen, in order to disperse the solution in the mesentery of the animal, thus favoring a faster absorption.

Then, tricotomy of the right thigh's posterior area was performed with a razor blade and, through an incision of approximately $2 \mathrm{~cm}$, the skin and subcutaneous mesh were opened.
The musculature was divulsed so as to locate the sciatic nerve and after its localization, $4 \mathrm{~mm}$ were removed, being the proximal stump directed backwards and sutured with a 50 thread, in the adjacent musculature, aiming at preventing a possible spontaneous reenervation. Soon afterwards, the surgical wound was closed with 4-0 thread.

After the surgery, the animals were put in cages warmed by incandescent light, so as to avoid hypothermia.

The operated animals were distributed into 3 groups: Group 1 comprised 10 animals that were sacrificed 4 weeks post-surgery; Group 2 was comprised of 10 animals that were sacrificed 10 weeks post-surgically, and so was Group 3, constituted by 10 animals, 15 weeks post-surgery.

The animals were sacrificed through an excess of anesthetic and the dissections of the right pelvic member were carried out, seeking the removal of the soleo and EDL muscles.

Histochemistry. The harvested muscles ( $\mathrm{m}$. soleo and $\mathrm{m}$. EDL) were divided into two parts and fixed in a formol solution (10\%) and in Bouin liquid for subsequent histological processing for the proposed techniques. The pieces that were fixed in formol, after the fixation time, were washed in tap water for $12 \mathrm{hrs}$ and transferred to a container with alcohol $70 \%$; the pieces fixed in Bouin, remained in this solution for 4 hours, being transferred to a container with alcohol $70 \%$, as well. Afterwards, the segments were processed for inclusion in paraffin. At completion of the paraffin blocks, the pieces were split up in a microtome so as to obtain cuts of $7 \mu \mathrm{m}$ in thickness and mounted in histological plates dyed in hematoxilyn eosin, in order to choose the best cuts to be submitted to the TUNEL technique.

The histochemical demarcation for the apoptosis used the ApopTag ® Plus Peroxidase In Situ (S7101) Kit protocol, according to the following procedures: (A) the unparafinnation of the pieces in xylol and dehydration in ethyl alcohol and distilled water; (B) treatment with proteinase $\mathrm{K}$ for $15 \mathrm{~min}$ at room temperature; (C) inhibition of the endogenous peroxides with peroxides of hydrogen at $2 \%$, for 5 min; (D) washing in PBS for 15 seconds; and (E) treatment with the transferase enzyme terminal (TdT) deoxinucleustide in a humidification chamber, at $37^{\circ} \mathrm{C}$, for 1 hour; (F) interruption of the reaction by the Stop/Wash buffer, for 30 min, at $37^{\circ} \mathrm{C}$; $(\mathrm{G})$ washing in PBS and treatment with the antidigoxygenine-peroxidase reagent for $30 \mathrm{~min}$, at room temperature; $(\mathrm{H})$ washing in PBS and treatment with the DAB (dimethylaminoazobenzene) chromate, for $6 \mathrm{~min}$, at room temperature; (I) washing in distilled water, contra-coloration with hematoxilyn of Harris and mounting between plate and cover glass with Enterlan resin (Merck, Germany). 


\section{RESULTS}

The dates of birth, the weights of the animals at surgeries and sacrifices, are demonstrated in Table I.

The results were obtained through a descriptive analysis of the plates through a digitalized image system coupled to an OLYMPUS B202 microscope. Thus, the cuts were mounted starting in the same portion of the soleo and EDL muscles so as to avoid possible variations in the results. Upon sacrifice, ulcerations were found in the right paw of 2 animals in the 10-week group and in 1 animal for the 15- week group. During the dissection and collection of the muscles, it was noticed that the muscles in the denervated paw presented an inferior dimension (atrophy) as compared to the innervated ones (Fig.1).

Two different fixatives were used, one for each group of samples, the liquid of Bouin and the formol 10\%, aiming at preserving, in the best way, the tissue of the muscles used and at favoring the application of the TUNEL and routine coloration techniques.

Table I. Relationship of the dates of birth and surgery, medium weight of the groups in the dates of the surgery and sacrifice of the animals utilized in the study.

\begin{tabular}{|c|c|c|c|c|c|c|}
\hline Groups & $\mathbf{N}$ & Date of birth & $\begin{array}{c}\text { Date of the } \\
\text { surgery }\end{array}$ & $\begin{array}{c}\text { Weight/ } \\
\text { surgery (g) }\end{array}$ & Sacrifice & $\begin{array}{c}\text { Weight/ } \\
\text { sacrifice (g) }\end{array}$ \\
\hline 4 weeks & 5 & 03/08/2005 & $15 / 09 / 2005$ & 125.5 & $13 / 10 / 2005$ & $240.7 \mathrm{~g}$ \\
\hline 4 weeks & 5 & 03/08/2005 & 16/09/2005 & 129.6 & $14 / 10 / 2005$ & $243.2 \mathrm{~g}$ \\
\hline 10 weeks & 5 & 04/08/2005 & 17/09/2005 & 125.5 & $26 / 11 / 2005$ & $375.6 \mathrm{~g}$ \\
\hline 10 weeks & 5 & 04/08/2005 & 18/09/2005 & 129.6 & $27 / 11 / 2005$ & $381.1 \mathrm{~g}$ \\
\hline 15 weeks & 5 & 04/08/2005 & 19/09/2005 & 138.1 & 02/01/2006 & $423.0 \mathrm{~g}$ \\
\hline 15 weeks & 5 & 04/09/2005 & 20/09/2005 & 144.0 & 03/01/2006 & $428.5 \mathrm{~g}$ \\
\hline
\end{tabular}
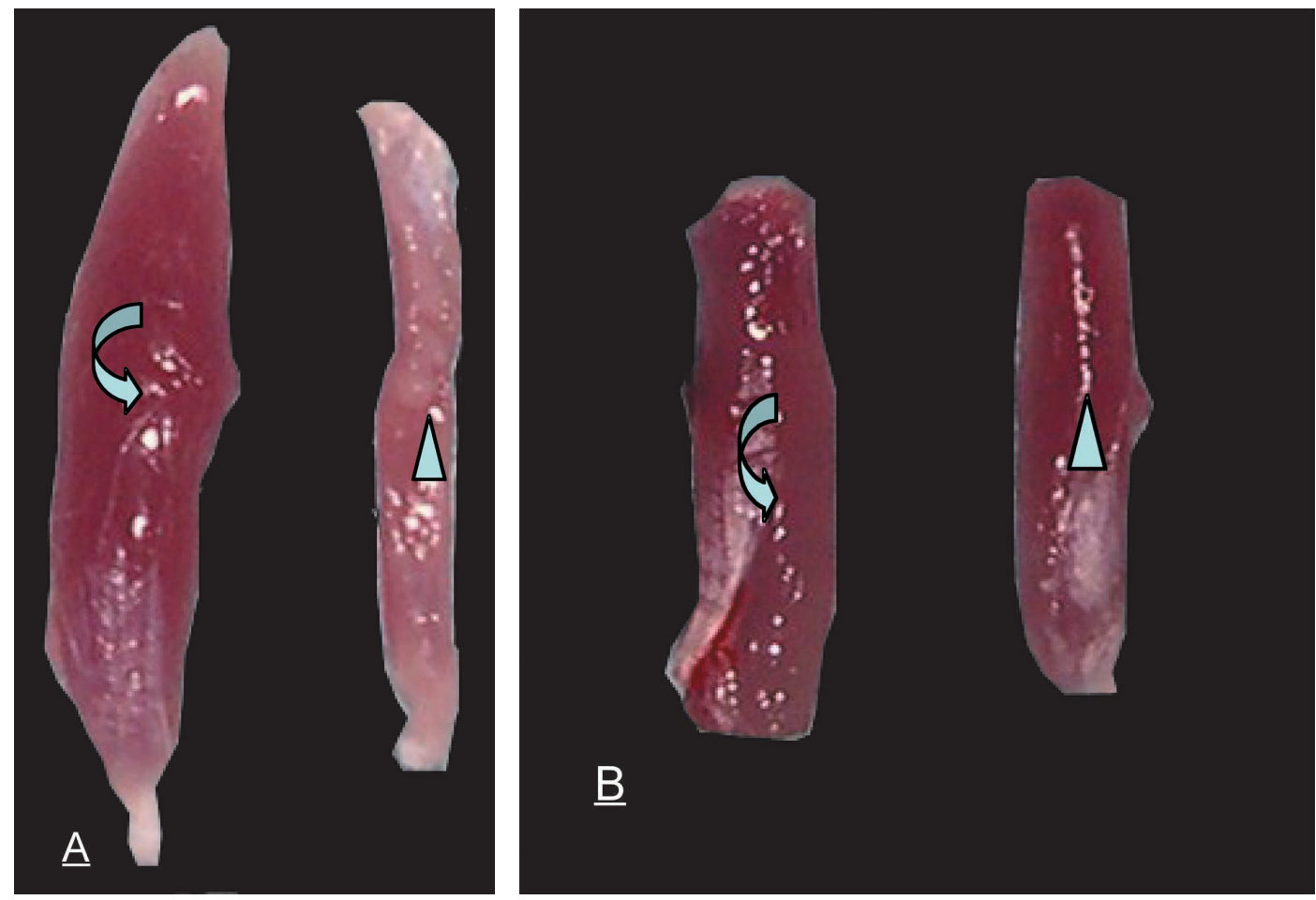

Fig 1. A. Normal muscle (arrow) soleo and denervation for 15 weeks (arrow head); B. Normal muscle (arrow) EDL and denervation for 15 weeks (arrow head). Notice a larger atrophy suffered by the red muscle (soleo). 

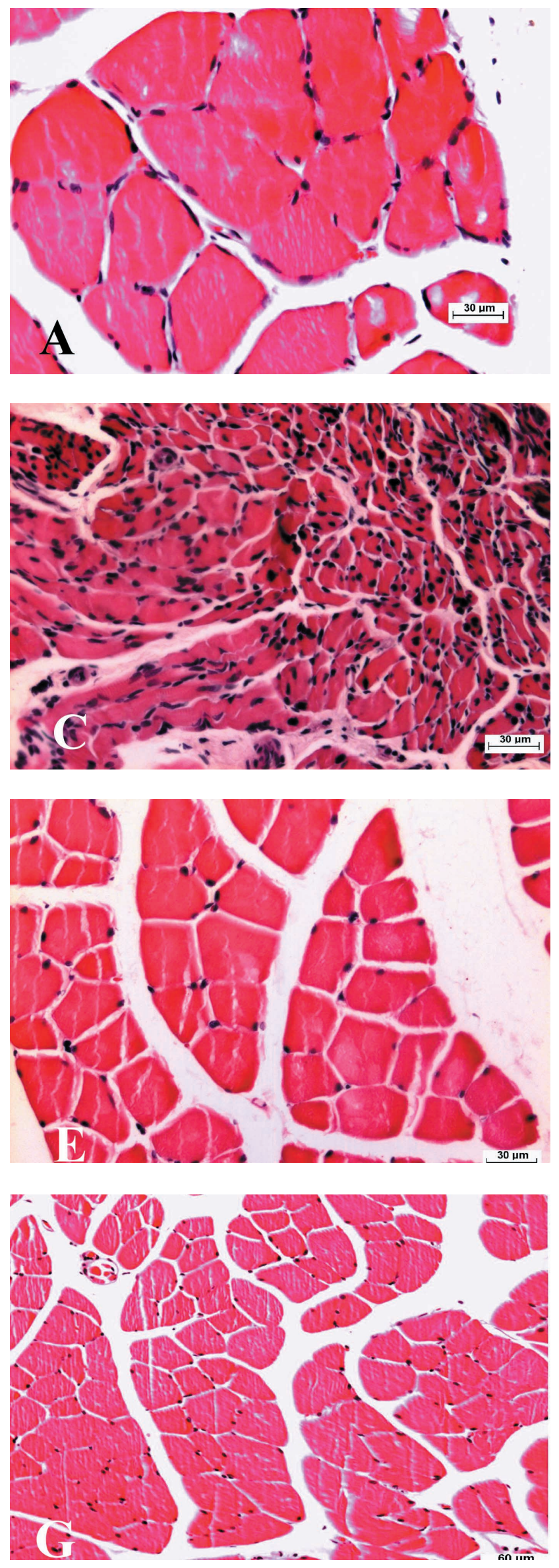
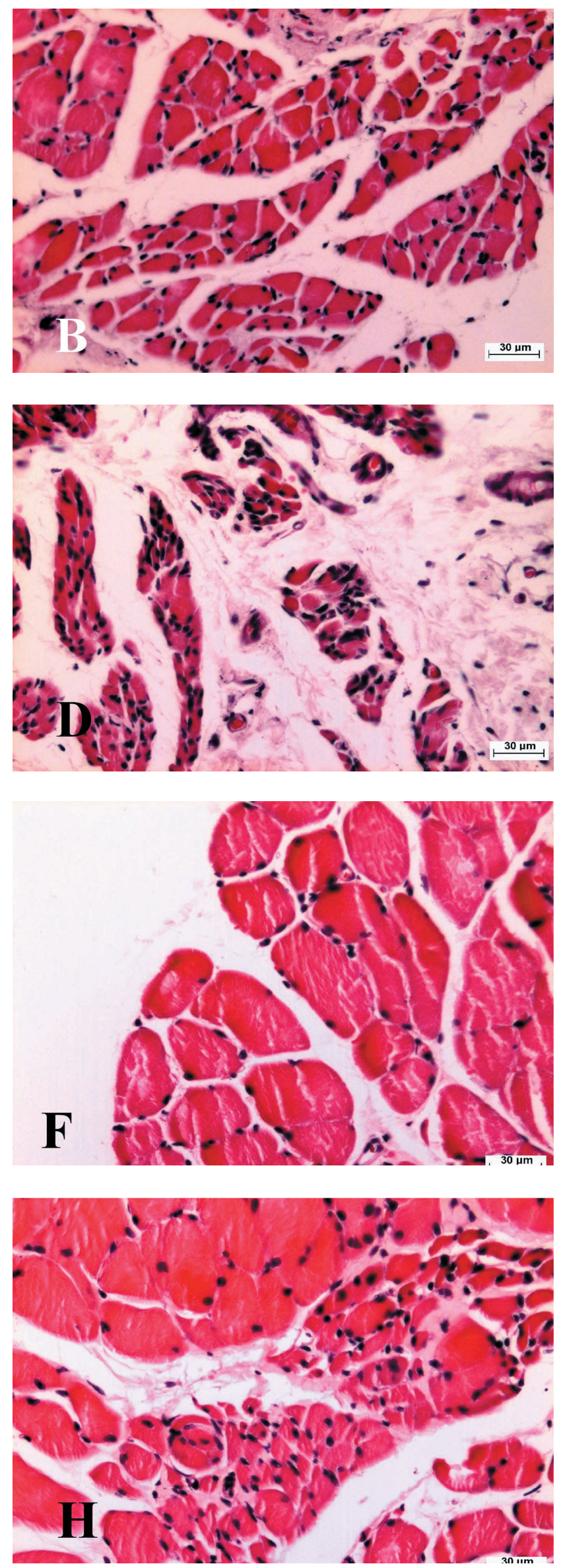
Fig. 2. Letters A to D refer to the soleo muscle: letter A refers to the normal muscle; letter B, refers to the muscle denervated for 4 weeks; letter $\mathrm{C}$, to the muscle denervated for 10 weeks and letter $\mathrm{D}$, to the muscle denervated for 15 weeks. Letters $\mathrm{E}$ to $\mathrm{H}$ refer to the EDL muscle: letter E refers to the normal muscle; F, to the muscle denervated for 4 weeks; $G$, to the muscle denervated for 10 weeks, and $\mathrm{H}$, to the muscle denervated for 15 weeks. Notice, in both muscles, the growing atrophy suffered by the muscles in post surgical time. Notice, too, the larger invasion of connective tissue into the soleo muscle, as compared to the EDL.

Before processing the material for the TUNEL technique, cuts (H.E.) were made for observation in a conventional optical microscopy. These cuts were utilized in the panoramic observation of the tissue so as to choose, later, the best cuts to be submitted to the TUNEL technique.

In panoramic observation, it was observed that in the normal group, there is a regularity as for the size and disposition of the fibers and this regularity is lost as the denervation period increases.

When we compared the soleo and EDL denervated muscles for the same period, in the same paw, we noticed that the red muscle was more affected by the denervation than the white muscle.

It was in the soleo muscle that we found a larger irregularity as for the number, size, and distribution of the fibers, with a larger invasion of the connective tissue, so that the irregularity aspect found in the soleo muscle, denervated for 4 weeks, presented a morphologic similarity to the EDL muscle, denervated for 15 weeks (Fig. 2).

After submitting the cuts to the TUNEL technique, they were photographed for the analysis and comparison of the different groups. Through a purely descriptive analysis, it was observed that the animals denervated for 4 weeks presented a larger frequency of positive TUNEL myonuclei (Fig. 3).

The use of the TUNEL technique allowed to observe the myonuclei of the researched animals and to analyze their morphology. This technique, specifically contributed to the identification of hyper-condensed chromatin. Thus, in the animals of the experimental groups, the hyper-condensed chromatins were observed in all groups, with a smaller incidence in the post- denervated 15 -week group, in the white muscle (m. EDL).

The form of the positive myonuclei, i.e., apoptotic myonuclei, differed from that of the normal myonuclei. The normal myonuclei, in general, presented larger, with a strawlike coloration (clearer), while the positive myonuclei for the technique were smaller, with a more intense coloration and the presence of a halo around of them. Myonuclei with these characteristics were observed scattered across the section, in an isolated way. The disposition of the chromatin in the positive myonuclei, exhibited a half-moon shape (Fig. 3).

\section{DISCUSSION}

During the surgery, some difficulty was seen as for the anesthesia, because of the margin of safety of the anesthetics and the recommended $(30 \mathrm{mg} / \mathrm{Kg})$ dose. Many of them still maintained the reflexes and a marked sensitivity in the inferior limbs, which required the supplement or increase in the dose.

Another difficulty was related to the anatomical variation of the sciatic nerve, especially as for the ramification of the nerve that in some instances, was above the expected place. After the surgery, the animals (5) were put in a cage as preconized by similar works (Rodrigues \& Schmalbruch). Even so, ulcerations were observed in the paw of two animals in the 10-week and 15-week experimental groups, post denervation. Such ulcerations, probably derive from autofagy.

Two types of skeletal striated muscles were used; a muscle commonly called red muscle, $\mathrm{m}$. soleo and a white muscle, m. EDL. In their researches, authors such as Rodrigues \& Schmalbruch; Borisov \& Carlson; Schmalbruch \& Lewis, 2000; Patterson \& Stephenson, 2006 have compared these two types of muscles, seeking to verify whether there are differences between them. The embryological origin is also quite compared in this investigation line, because, muscles of a branchiomeric origin, many times respond differently from the other striated muscles of a myotomic origin.

In the experimental groups, without exception, there was an atrophy of the muscular belly of the two researched muscles. That atrophy can be observed at the naked eye, upon collection, and is consistent with the literature (Duke et al., 1996).

At the microscopic level, an increase of the space is observed among the fascicles of the fibers, with an invasion of connective tissue in these spaces. In the soleo muscle, this invasion happens in an accentuated and precocious (in the 4-week post-denervation group) way, as compared to the EDL muscle. These results are consistent with those obtained by other authors (Borisov \& Carlson; Rodrigues \& Schmalbruch) who studied these alterations in red and white muscles. 


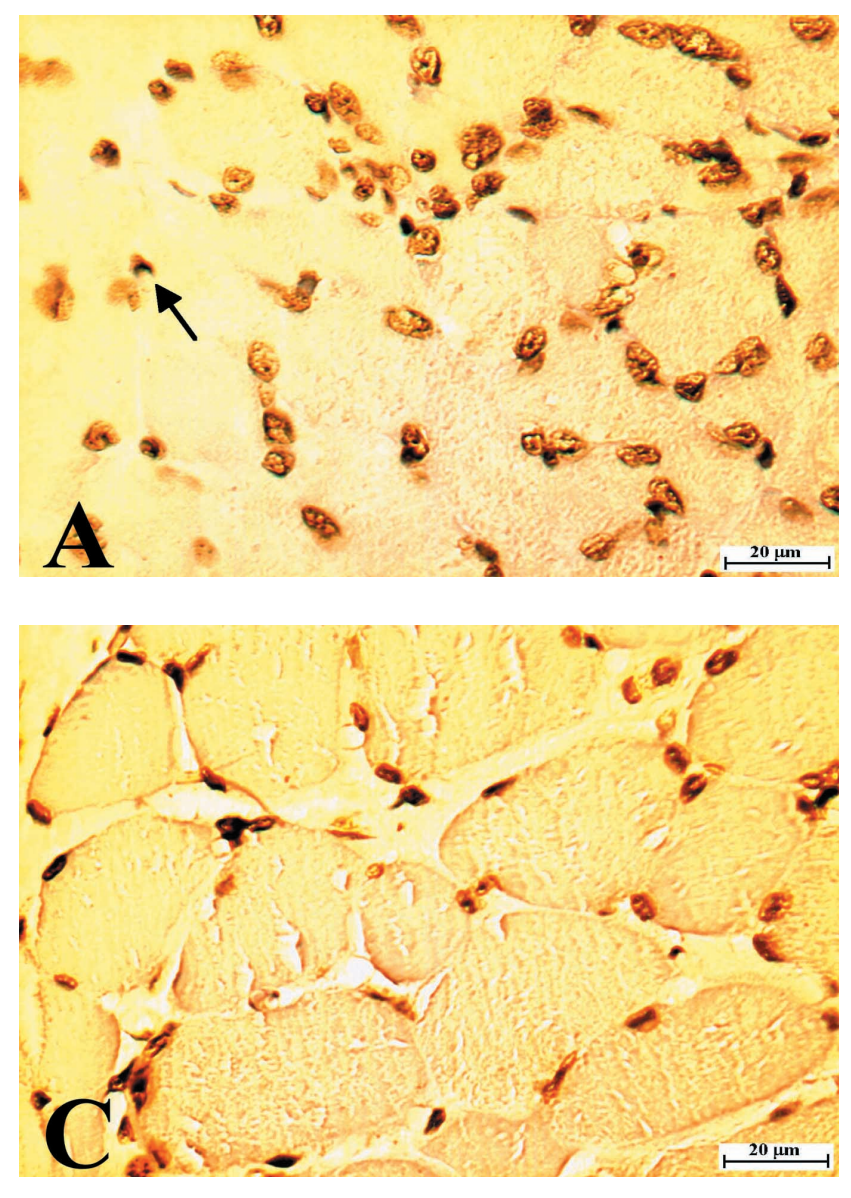

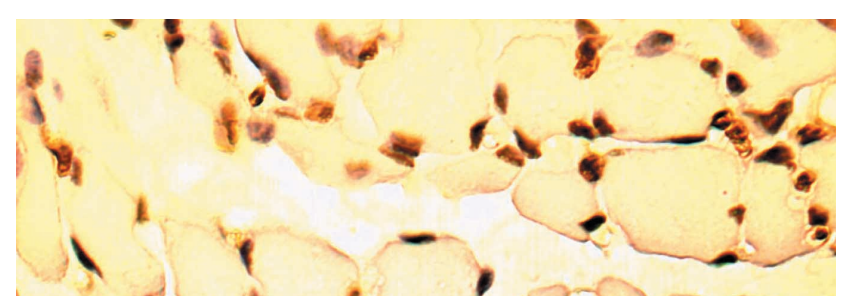

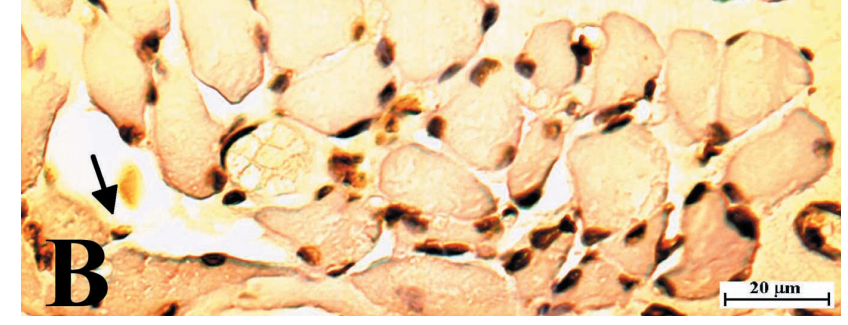

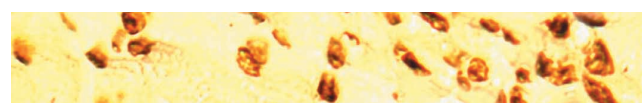

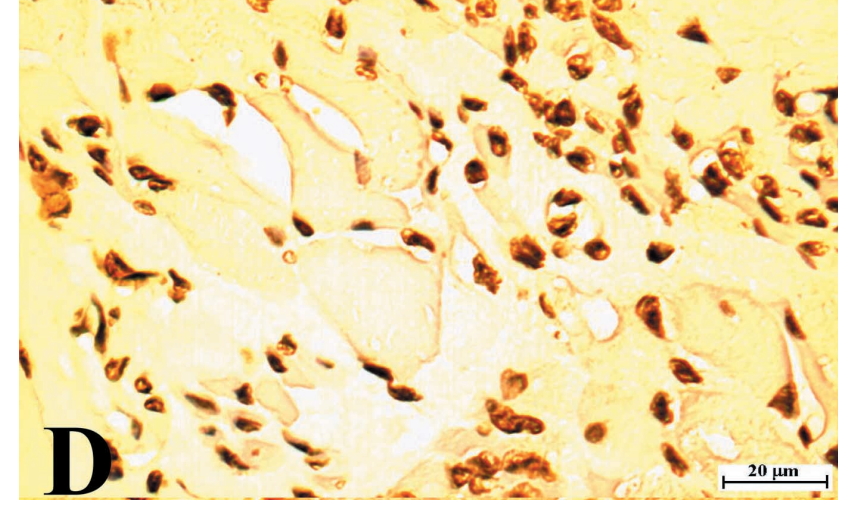
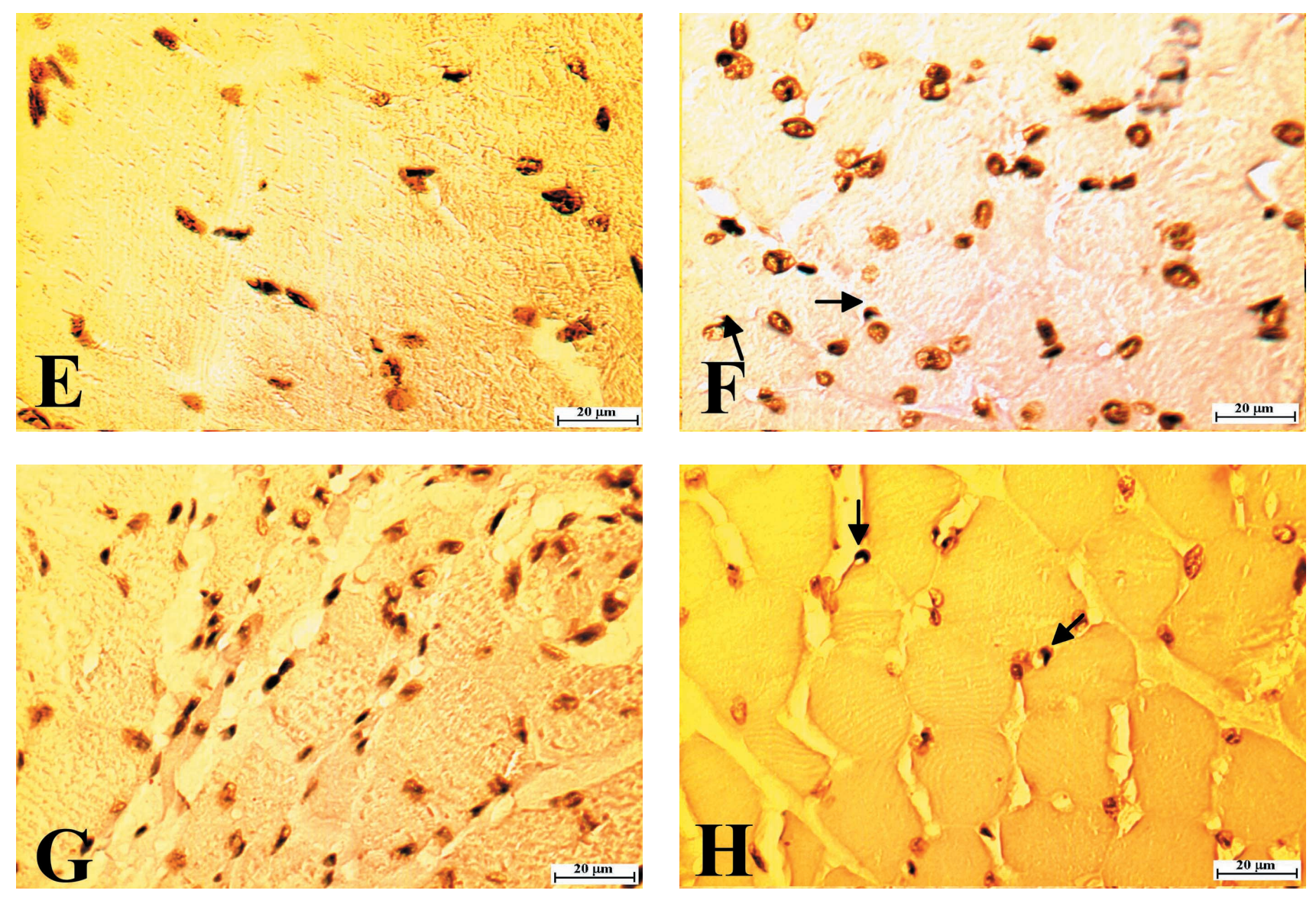
Fig. 3. Muscular fibers submitted to the TUNEL technique. Letters A to D refer to the soleo muscle, while letters $\mathrm{E}$ to $\mathrm{H}$ refer to the EDL muscle. The arrows point to myonuclei with apoptotic characteristics. In A, normal soleo muscle and in $\mathrm{B}, \mathrm{C}$, and $\mathrm{D}$, muscles denervated for 4,10 and 15 weeks, respectively. Likewise, in E, normal EDL muscle, while in $\mathrm{F}, \mathrm{G}$ and $\mathrm{H}$, EDL muscles denervated for 4,10 and 15 weeks, respectively.

Regarding the presence of apoptosis in the normal and experimental groups, our results clearly show that the cell death, through this process, is an important component that contributes to the characteristics observed in the denervated muscle.

A purely descriptive study has been carried out on the characteristics of the apoptosis phenomenon with no statistically assessed quantitative data. This is due to the cost of the technique employed. The results obtained by means of this descriptive analysis are in agreement with detailed descriptions of previous works (Kerr, 1971; Kerr et al., 1972; Wyllie, 1981; Borisov \& Carlson). Furthermore, apoptosis in skeletal striated muscular fibers, in some aspects, is similar to that observed by Kerr et al. (1974) in the tadpole's tail, during metamorphosis.

A retracted nucleus with condensed chromatin of the sarcolemus was observed in positive cells in the TUNEL technique. These results are consistent with those obtained by authors that studied the alterations which take place in muscles denervated for a long period, in adult animals (Anzil \& Wernig, 1989; Rodrigues et al.).

It is worthwhile to highlight that previous research by Rodrigues \& Schmalbruch, pointed to the absence of apoptosis in muscles denervated for long periods. On that occasion, the in situ Nick Translation and Tail techniques were used to identify apoptotic myonuclei.

The observations in the ultra-structural levels (MET) of previous works which pointed to the presence of apoptosis in the mentioned muscles, led us to accomplish new researches with the same goals. In addition, on that occasion, our plates were compared to those processed by other authors, using the thymus of mice, years ago. Indeed, this, by itself, would be a good reason for new trials.

In similar work recently accomplished by our group (Rodrigues et al.), in the same investigation line, employing the Comet Essay Technique, the occurrence of apoptosis in muscles denervated for a long period was explicit. In the present investigation, we decided to use the TUNEL technique, since it is the most accepted one by the scientific community.

Although we do not fully agree, some authors suggest that the apoptosis phenomenon in muscles differs from that of other tissues (Borisov \& Carlson). For these authors, the particularities of cell death in denervated muscles are very similar to those observed in a normally developing muscle, thus relating a common way of cell death between the two situations. In our opinion, in the case of denervated muscles, the loss of main cell function (contraction) plays a crucial part in triggering the cascade of cell phenomena that determine the apoptosis. If our suggestion is correct, it would be possible to manipulate this phenomenon, that is, begin it by removing themain function from the cell, so as to avoid energy waste, thus, favoring the elimination of noxious cells in diseases such as cancer.

It is interesting to notice, also, that other researchers (Ekshyyan \& Aw, 2004) attribute to a variety of illnesses such as Alzheimer, Parkinson, Huntington, amyotrophic lateral sclerosis, hemorrhages and many other neurodegenerative illnesses, the capacity to induce precocious apoptosis. These authors researched such phenomenon in neurons, emphasizing the main progress in the research methodology with the use of models of mutant animals. Taking this possibility into account, greater efforts shall be put into the research of degenerative illnesses of the muscular tissue, such as dystrophies, in an attempt to establish some correlation with the findings of the aforementioned researchers. In that connection, new projects are being elaborated by our team, focusing on degenerative pathologies of the skeletal striated muscle and the use of mutant animals related to these diseases.

DAVATZ, C. G.; ANDREO, J. C.; RODRIGUES, C. A.; ROSA JÚNIOR, G. M. \& MORAES, R. L. H.. Apoptosis en músculo estriado desnervado. Int. J. Morphol., 25(3):529-536, 2007.

RESUMEN: El fenómeno apoptosis ocurre en tejidos normales y en muchas condiciones patológicas, de acuerdo a lo relatado en varios trabajos. El estudio de este fenómeno tuvo su apogeo en la década del 70, permaneciendo en el olvido hasta la década del 90, momento en el cual comienzan a surgir técnicas más avanzadas, que motivaron su retorno a laboratorios de todo el mundo. Así, técnicas de microscopía electrónica, histoquímica, ensayos cometa, etc., fueron utilizados en los esfuerzos de elucidar de forma más profunda los mecanismos que conllevan a la célula al "suicidio". No se puede negar la importancia del conocimiento de ese fenómeno o, más específicamente, del control de su inducción o bloqueo para el tratamiento de patologías como el cáncer, por ejemplo. El presente trabajo tuvo como objetivo el estudio de apoptosis en músculo inervados, por diferentes periodos. También fueron comparados dos tipos de músculo estriado, el llamado músculo rojo (m. sóleo), resistente a la fatiga y de contracción lenta, un músculo blanco (m. EDL) de fatiga precoz y contracción rápida. Este trabajo hace parte de un proyecto mayor ya desarrollado por sus ejecutores, sólo que utilizando la técnica del TUNEL como herramienta principal para identificar la apoptosis. Fue demostrado que tal fenómeno ocurre de forma más acentuada en los momentos iniciales de la desnervación. Además de eso, fue observado que el músculo rojo responde de manera más intensa a la desnervación. Nos parece inferir que la retirada de la principal función celular, en el caso del músculo estriado, la contracción despierta un mecanismo cuya reacción en cadena culmina en apoptosis. Otros proyectos están siendo elaborados con el propósito de utilizar animales mutantes, para estudiar enfermedades musculares degenerativas y correlacionarlas a la desnervación. 


\section{ACKNOWLEDGEMENTS}

We would like to thank FAPESP for the financial grant and to Nicolas Bertolaccini Santos for the technological support.

\section{REFERENCES}

Anzil, A. P. \& Wernig, A. Muscle fibre loss and reinnervation after long-term denervation. J. Neurocytol., 18(6):833-45, 1989.

Borisov, A. B. \& Carlson, B. M. Cell death in denervated skeletal muscle is distinct from classical apoptosis. Anat. Rec. 258(3):305-18, 2000.

Borisov, A. B.; Dedkov, E. I. \& Carlson, B. M. Interrelations of myogenic response progressive atrophy of muscle fibers, and cell death in denervated skeletal muscle. Anat. Rec. 264(2):20318, 2001.

Duke, R. C.; Davia, M. \& Young, J. D. Cell suicide in health and disease. Sci. Am., 148:48-55, 1996.

Ekshyyan, O. \& Aw, T. Y. A Key in Neurodegenerative Disorders. Curr. Neurov. Res., 1(4):355-71, 2004.

Gavrieli, Y.; Sherman, Y. \& Ben-Sasson, S.A. Identification of programmed cell death in situ via specific labeling of nuclear DNA fragmentation. J. Cell Biol.,119:493-501,1992.

Grütter, M. G. Caspases: Key players in programmed cell death. Curr. Opin.Struct. Biol., 10(6):649-55, 2000.

Hengarthner, M. O. The biochemistry of apoptosis. Nature, 407:770$6,2000$.

Kerr, J. F. R.; Wyllie, A. H. \& Currie, A. R. Apoptosis: a basic biological phenomenon with wide-ranging implications in tissue kinetics. Br. J. Cancer, 26:239-44, 1972.

Kerr, J. F. R. Shrinkage necrosis: a distinct mode of cell death. J. Pathol., 105:13-6, 1971.

Kerr, J. F. R.; Harmon B. \& Searle, J. An electron-microscope study of cell death in the anuran tadpole tail during spontaneous metamorphosis with special reference to apoptosis of striated muscle fibers. J. cell Sci., 14:571-8, 1974.

Knaapen, M. W. M; Davies, M. J.; De Bie, M.; Haven, A. L.; Martinet, W.; Kockx, M. M.; Apoptotic versus autophagic cell death in heart failure. Cardiovasc. Res., 51(2):304-12, 2001.

Patterson, M. F.; Stephenson, D. G. Denervation produces different single fiber phenotypes in fast- and slow-switch hindlimb muscles of the rat. Am. J. Physiol. Cell. Physiol., 291(3):51828, 2006.
Rodrigues, A. C.; Dolfini, M. I. M.; Geuna S.; Andreo, J. C. \& Rodrigues, S. P. M. Apoptosis in long-term denervated rat skeletal muscle. Braz. J. Morphol. Sci., 22(4):129-36, 2005.

Rodrigues, A. C. \& Schmalbruch, H. Satellite cells and myonuclei in long-term Denervated rat muscles. Anat. Rec., 243(4):430-7, 1995.

Schmalbruch, H. \& Lewis, D. M. Dynamics of nuclei of muscle fibers and connective tissue cells in normal and denervated rat muscles. Muscle Nerve, 23(4):617-26, 2000.

Tang, H.; Cheung, W. M. W.; Ip, F. C. \& Ip, N.Y. Identification and characterization of differentially expressed genes in denervated muscle. Mol. Cell. Neurosci., 12(2):127-40, 2000.

Tews, D. S.; Behrhof, W. \& Schindler, S. Expression patterns of initiator and effector capsades in denervated human skeletal muscle. Muscle Nerv., 31(2):175-81, 2005.

Tischeler, M.E. et al. Different mechanisms of increased proteolysis in atrophy induced by denervation or unweighting of rat soleus muscle. Metabolism, 39:756-63, 1990.

Van Cruchten, S. \& Van Den Broeck, W. Morphological and biochemical aspects of apoptosis, oncosis and necrosis. Anat. Histol. Embryol., 4(31):214-23, 2002.

Washabaugh, C. H.; Ontell, M. P.; Kant, J. A.; Daood, M. J.; Watchko, J. F.; Watkins, S. C. \& Ontell, M. Effect of chronic denervation and denervation-reinnervation on cytoplasmic creatine kinase transcript accumulation, 47(3):194-206, 2001.

Weis, J.; Kaussen, M.; Calvo, S. \& Buonanno, A. Denervation induces a rapid nuclear accumulation of MRF 4 in mature myofibers. Dev. Dyn., 218(3):438-51, 2000.

Wyllie, A. H. Cell death: a new classification separating apoptosis from necrosis. In: Cell death in biology and pathology (ed. I.D. Bowen and R.A. Lockslin). Chapman and hall, London, 9, 1981.

Zimmermann, K. C.; Bonzon, C. \& Green, D. R. The machinery of programmed cell death. Pharmacol. Ther., 92(1):57-70; 2001.

\section{Correspondence to:}

Prof. Dr. Antonio de Castro Rodrigues

Depto. de Ciencias Biológicas

Faculdade de Odontologia de Bauru

Universidade de São Paulo

Al. Dr. Octávio Pinheiro Brisolla, 9-75

CEP 17012-901

Bauru - SP

BRASIL

Received: 26-03-2007

Accepted: 18-05-2007 